\title{
Mükemmeliyetçiliğin İş Performansına Etkileri: Aşçılar Üzerine Bir Araştırma ${ }^{1}$
}

Effects of Perfectionism to Job Performance: An Investigation on Chefs

\author{
Serdar EREN*, Ebru GÜNLÜ KÜÇÜKALTAN** \\ * Dr., Bağımsız Araştırmacı, Çamlıca Mahallesi, Ulusal Egemenlik Bulvarı 164/6 , PK 26180, Eskişehir. \\ E-posta: chefserdar75@gmail.com \\ ORCID: 0000-0001-9733-2308 \\ ** Prof. Dr., Dokuz Eylül Üniversitesi, Turizm İşletmeciliği Bölümü, PK 35370, Tınaztepe Yerleşkesi, İzmir. \\ E-posta: ebru.gunlu@deu.edu.tr \\ ORCID: 0000-0003-2599-0197
}

MAKALE BILGILERI

Makale işlem bilgileri:

Gönderilme tarihi:13 Mart 2017

Düzeltme: 9 Haziran 2017

Düzeltme: 29 Haziran 2017

Kabul: 7 Temmuz 2017

Anahtar sözcükler:

Mükemmeliyetçilik, İş performansı, Aşçılar.

\section{ARTICLE INFO}

Article history:

Submitted: 13 March 2017

Resubmitted: 9 June 2017

Resubmitted: 29 June 2017

Accepted: 7 July 2017

Key words: Perfectionism, Job performance, Chefs.

\section{ÖZ}

Bu çalışmanın amacı uluslararası zincir otellerde çalışan şefler örnekleminde, mükemmeliyetçilik ve iş performansı arasındaki etkileşimi incelemektir. Şeflerin iş yaşamında kendilerini yeterli görmeme, kendilerine yüksek standartlar belirleme, bașkalarına yönelik ve bașkalarınca dayatılan mükemmeliyetçi tutumlarının bireysel iş performanslarını etkileyen faktörler olduğu varsayılmıştır. Anket, amaca göre örnekleme yöntemi uygulanarak, İstanbul bölgesi zincir otellerinde çalışan aşçılara, profesyonel sektör toplantıları esnasında uygulanmıștır. Bu kapsamda çalıșmada, tanımlayıcı istatistik tekniklerinden açıklayıcı faktör analizi ve regresyon analizi kullanılmıștır. Analiz sonuçları, șeflerde mükemmeliyetçilik ile iș performansı etkileșiminin sınırlı olduğunu göstermektedir. Bulgular ışığında otel insan kaynakları yöneticilerine ve akademisyenlere önerilerde bulunulmuştur.

\begin{abstract}
The purpose of this study is to investigate the interaction between perfectionism and job performance in the sample of chefs working at international chain hotels. It's assumed that chefs perceive themselves as inadequate at work, set very high standards, have perfectionistic attitudes towards others and the same attitudes imposed on them by others are the factors affecting their job performance. By using the purposive sampling method, the questionnaire was applied to the chefs working at international chain hotels during the professional meetings in Istanbul Region. In this context at the study descriptive statistical techniques such as; explanatory factor analysis and regression analysis are used. Results of the analysis show that the interaction between perfectionism and job performance in chefs is limited. Suggestions were given to the hotel human resources managers and academcians in accordance with research findings.
\end{abstract}

\section{Giriş}

Yiyecek ve içecek işletmelerinin hızlı ve gelişen yapısı içinde çalışanların kişilik özellikleri ön plana çıkmakta ve çalışanların içinde bulundukları mesleğin doğasına uyum sağlamaları ölçüsünde başarı yakalanmaktadır. Bu noktada insan kaynakları yöneticileri örgütün amacına ve başarısına ulaşmak amacıyla; iş görenlerin seçimin-

\footnotetext{
${ }^{1}$ Bu makale, Serdar Eren'in Dokuz Eylül Üniversitesi Sosyal Bilimler Enstitüsü'nde yazılan "Mükemmelliyetçiliğin İşgören Performansına Etkisi: İstanbul İli Uluslararası Zincir Otel İșletmelerinde Çalışan Orta Kademe Mutfak Yöneticileri Üzerine Bir Araştırma" başlıklı doktora tezinden derlenmiştir.
}

de ve değerlendirilmesinde kişilik özellikleriyle (girdi), iş performansları (çıktı) arasındaki ilişkileri anlamak ve yorumlamak yönünde çalışmalar yapmaktadırlar.

İş yaşamında var olan ve durumsal uyarıcı niteliği taşıyan sosyal düzeydeki, görev düzeyindeki ve örgüt düzeyindeki beklentiler, ilişkili oldukları belirli kişilik özellikleri üzerinde etki yaratırlar. Bu etkileşimin sonucunda çalışanlar belirli davranışlar gösterirler (Tett ve Burnet 2003, Yelboğa 2006). Dolayısıyla, iş yaşamının gerekleri olan stardart hale getirilmiş kalite sistemleri, mükemmellik modelleri, başarı ödüllendirmeleri 
gibi faktörler kişilik özellikleri ve beklentiler ile birleştiğinde davranış yönlü çıktılara ulaşılmaktadır. Bu çıktılar kişiyi başarı ve motivasyon anlamında üst seviyelere çıkarabildiği gibi stres, tükenmişlik ve depresyon sebebiyle, iş içinde ve iş dışında bulunan kişilerle çatışma yönlü davranışlara da itebilir. Bu davranışlar çalışanların işten soğumaları ya da ayrılmaları gibi istenmeyen durumlara yol açabilmektedir. Aşçılık mesleğinin doğası gereği tutkulu ve enerjik olması, mesleğin değerlerinin mükemmel yeteneklerle ölçülmesi gibi etkenler, çatışma ve işten ayrılma gibi durumların sıklıkla yaşanmasına yol açmaktadır (Zetie vd. 1994; Robinson ve Barron 2007). Son yıllarda ünlü şeflerin artan intihar olayları da kişilik özellikleri ve iş performansı etkileşiminin bir sonucu olarak ortaya çıkmaktadır (Eburne 2010; Steinberger 2016). Bu durum mükemmeliyetçilik gibi farklı kişilik özelliklerinin iş yaşamı ile ilişkilerini araştırmayı gerekli kılmaktadır.

Son yıllarda mükemmeliyetçiliğin çalışma yaşamında yarattığı etkilerin araştırılmasına yönelik akademik çalışmalar artmaya başlamıştır. Bu çalışmalar önceleri sanatçılar (Mor vd. 1995), ergen ve okul çağındaki gençler (Rice ve Dwello 2002; Stoeber ve Eysenck 2008) ve sporcular (Anshel ve Mansouri 2005) üzerinde yapılmış, sonrasında örgütsel davranış bilimine doğru yönelmiştir. Mükemmeliyetçiliğin iş yaşamı ve davranışlara olan etkisini araştıran Monck (2009) iş performansının alt konularından biri olan örgütsel vatandaşlık davranışı ile kuvvetli ve olumlu bir ilişki içinde olduğu sonucuna varmıştır. Hralbuik (2009) polis memurlarında mükemmeliyetçiliğin azami ve tipik performans ile ilişkilerini incelemiş ve mükemmeliyetçilerin amaç belirleme davranışlarıyla azami iş performansları arasında olumlu bir ilişki olacağını, tipik performans durumunda ise mükemmeliyetçiliğin iş performansı ile olumsuz bir ilişkide olacağını öne sürmüştür. Baker ve Newport (2003) normal dışı yönetici olarak nitelendirdikleri mükemmeliyetçiler ile birlikte çalışanların sabit stres ile baş edememeleri, fazladan izin günü istemeleri, kapasitelerini etkin kullanamamaları ve kendilerini örgütten ayırdıkları gibi olumsuz etkilere maruz kaldıklarını açıklamışlardır. Alanyazında kişilik özellikleri, iş yaşamı ve iş performansı arasında- ki ilişkileri sorgulayan araştırmalar oldukça fazla iken onaltı faktörlü büyük kişilik envanterinin bir parçası olan mükemmeliyetçiliğin iş yaşamındaki etkilerine yönelik yapılan araştırmaların sayısı oldukça sınırlıdır. Yapılan bazı araştırmalarda üniversite öğrencilerinin çalışma hayatına ilişkin yüksek mükemmeliyetçi beklentileri olduğu (Stoeber ve Stoeber 2009), işkoliklik (Stoeber vd. 2013; Tziner ve Tanami 2013), tükenmişlik (Childs ve Stoeber 2010; Li vd. 2014) gibi kavramların mükemmeliyetçilikle çok yakın ilişkili olduğu, mükemmeliyetçiliğin iş hayatında yaşanan anlaşmazlıklara karşı hoşgörüsüzlük davranışlarını tetiklediğinden dolayı düşük iş tatmini yarattığ 1 (Fairlie ve Flett 2003; Wittenberg ve Norcross 2001), yüksek kalitede performans sağladığ durumlarda verimliliğin ve üretkenliğin düşük olduğu (Sherry vd. 2010; Stoeber ve Eysenck 2008) gibi sonuçlar ortaya konmuştur.

$\mathrm{Bu}$ çalışma, yönetim ve turizm işletmeciliği alanyazınlarında söz konusu değişkenlerin bir arada incelendiği çalışmaların sayısı oldukça sınırlı olması sebebiyle, mükemmeliyetçilik kavramına açıklık getirmekte ve bu çerçevede alanyazına katkı sağlamayı amaçlamaktadır. Turizm işletmelerinin bir meslek kolu olarak nitelendirilen aşçılık alanında mükemmeliyetçiliğin iş performansında etkili olup olmadığını anlamak ve turizm işletmeciliği ile örgütsel davranış alanlarındaki bir eksikliği sorgulamak üzere tasarlanan bu araştırmanın, uygulamada özellikle performans ölçme ve değerlendirme süreçlerinde mükemmeliyetçilik faktörünün göz önüne alınmasının önemini hatırlatır nitelikte olacağı ve örgütlere yönetsel anlamda katkı sağlayacağı düşünülmüştür.

\section{ALANYAZIN TARAMASI}

Araştırmanın bu bölümünde iş performansı ve mükemmeliyetçilik değişkenlerine ilişkin alanyazın incelemesi yapılarak aralarındaki etkileşimi ortaya koyan çalışmalar irdelenmiştir. Bu çalışmalar ışığında belirlenen hipotezler bölüm sonunda aktarılmıştır.

\section{İş Performansı}

Yirminci yüzyılın ikinci yarısından itibaren performans araştırmaları hem psikoloji hem de in- 
san kaynakları araştırmacılarının ilgisini çekmiş, çalışanların işe alımları ve iş yerindeki çalışma hayatları boyunca değerlendirilmeleri performans konusunun önemini oldukça arttırmıştır. Bu süreçte araştırmacılar çalışmalarını değerlendiricilerin ya da denetçilerin değerlendirme esnasındaki tutumlarına (Landy ve Farr 1980) doğru yönelterek iş performansı konusundaki ilk modellerin (Campbell 1990; Borman 1990) ortaya çıkmasına zemin hazırlamışlardır. Campbell tarafından performansın belirleyicileri ile ilgili ortaya konan model, üç belirleyici faktör altında sekiz boyutludur. Bu boyutlar; işe özgü görev yetkinliği, işe özgü olmayan görev yetkinliği, yazılı ve sözlü iletişim görev yetkinliği, çaba gösterme, kişisel disiplini koruma, grup ve takım performansını iyileştirme/arttırma, gereken durumlara göre gözetim/liderlik ve yöneticilik/idareciliktir. Viswesvaran (1993) tarafından önerilen dokuz boyutlu modelin Campbell (1990) modeli ile uyumlu yanları bulunmakla beraber, organizasyonların sonuç yönlü performanslarının kalitatif ve kantitatif faktörler ile ölçülmesi gerektiğinin önemine işaret eden bir farklılığının bulunduğu söylenebilir. Viswesvaran'in dokuz boyutu; genel iş performansı, iş performansı ve üretkenlik, çaba, iş bilgisi, kişiler arası ilişkilerde yetkinlik, idari yetkinlik, kalite, iletişim yetkinliği, liderlik ve kurallara uymadır. İş performansı alanyazınında en çok atıf yapılan sınıflandırma niteliğindeki model, Borman ve Motowidlo'nun iş performansını görev performansı ve ortamsal (kurumsal) performans olarak iki değişken ile inceledikleri modeldir (Sonnentag ve Frese 2002: 6). Görev performansı kişinin, organizasyonun teknik yapısına katkıda bulunacak şekilde icra ettiği aktivitelerindeki bireysel yeterlilik anlamına gelmektedir. Bu katkı, üretim işçilerinin direkt katkıları ya da çalışanların veya müdürlerin dolaylı katkıları şeklinde ortaya çıkabilir. Ortamsal (kurumsal) performans ise organizasyonun teknik yapısina katkıda bulunmayan, ancak organizasyonun hedef ve amaçlarının takip edildiği yönetimsel, sosyal ve psikolojik çevreyi destekleyen aktiviteleri anlamina gelmektedir (Borman ve Motowidlo 1993: 94).

\section{Mükemmeliyetçilik}

Günlük hayatta sıkça rastlanan "mükemmel" kelimesi toplumun en alt kesiminden en üst kesimine kadar iş hayatında başarılı ya da hayal ettikleri konumda olabilmeleri için yüksek bir değerlendirme ölçüsü sayılmaktadır. Sıklıkla kullanılan mükemmel iş, mükemmel çalışma, mükemmel oyun ve mükemmel performans betimlemeleri kişilerin, kişilik özellikleri ve davranışlarının eşsiz bir kombinasyonunu yansitmaktadır (Bousman 2007).

Mükemmeliyetçilik, kusursuzluk için çabalayan, performans için çok yüksek standartlar koyan ve her zaman bu duyguları taşıyan insanların genel davranışları olarak tanımlanmaktadır (Hill vd. 1997: 81; Flett ve Hewitt 2002: 5). Bu tanıma ek olarak mükemmeliyetçiliğin bir kişilik özelliği olduğunu ve kişilerin bu özelliklerinden doğan tüm davranışlarının sebebi olduğunu belirtmekte fayda vardır.

Mükemmeliyetçi insanlar genel anlamda kusursuzluğa ulaşmaktan zevk alan, bu durumu yaşamlarının bir parçası haline getiren, her zaman reddedilmenin endişe ve korkusunu taşıyan ve bu duygusal tepkiler ile herhangi bir tehdit unsuru olduğuna inandığı durum ya da durumlar karşısında yoğun derecede heyecan ve stres ile karşı karşıya kalan kişilerdir (Habke ve Flynn 2002: 157).

Mükemmeliyetçiliğin ilk olarak Freud'un kişilik özellikleriyle ilgili çalışmalarında kullanıldığ1 görülmektedir. Freud, kişideki süper egonun aileden kaynakladığını ve çocukluk döneminde ailenin istekleri doğrultusunda şekillendiğini ifade etmiştir. Süper egonun kusursuz olma isteği mükemmeliyetçiliği temsil eder (Monck 2009: 6; Tuncer 2016: 14-15). Bu durum kişileri farklı alanlarda işleri kusursuz yapmaya itmesi dolayısıyla, ideal bir koca, ideal bir evlat veya hostes olmalarını gerektirir (Horney 1996: 207).

Mükemmeliyetçiliğin boyutsal tartışmaları tek boyutlu olduğunu savunan Ellis'in akılcı olmayan inançları ve normal dışı davranışları ile Burns'ün işlevsel olmayan tutumları gibi bilişsel faktörlere odaklanırken (Flett ve Hewitt 2002: 10; Ulu 2007: 15) çok boyutlu olduğunu savunanlar 
mükemmeliyetçiliği bireyin kendisi ve çevresiyle alakalı bilişsel ve sosyal boyutlarını ortaya koymak için çalışmalar yapmışlardır. Hewit ve Flett (1991a) mükemmeliyetçiliğin; kendine karşı, diğerlerine karşı ve sosyal olmak üzere üç boyutu olduğunu savunmuşlardır.

Frost vd. (1990) mükemmeliyetçiliği, hatalara karşı aşırı ilgi, yüksek kişisel standartlar, yüksek ailevi/ebeveynsel beklentiler, ailevi eleştiri algılaması, kendi hareketlerinin kalitesine karşı kuşkuculuk, düzen ve organizasyon ile ilgili tercihler olmak üzere altı boyuttan oluştuğunu öne sürmüşlerdir.

Slaney vd. (2001) ise mükemmeliyetçiliğin uyumlu ve uyumsuz olmak üzere iki kısımda incelenebilen, yüksek standartlar, düzen ve organizasyon ve çelişki olmak üzere üç temel alt ölçeği bulunan bir hibrid model olduğu görüşünde birleşmişlerdir.

\section{Hipotezlerin Belirlenmesi}

Araştırmada kullanılan ölçeğin orijinalinden farklı olan yeni bir faktöre ulaşıldığ 1 için daha önceden belirlenen altı adet hipoteze ek olarak iki adet yeni hipotez belirlenmiştir. Araştırmanın değişkenleri arasındaki ilişkiyi belirlemek üzere oluşturulan hipotezlerin test edilmesine yönelik olarak yapılan analiz sonuçları bulgular ve tartışma bölümünde irdelenmiştir.

Kendine yönelik mükemmeliyetçi davranışlar bireyin kendisine ait olan ulaşılamayacak ve mantık dışı yüksek standartlar koyma ile kendini eleştirme olarak ortaya çıkar (Hewitt ve Flett 1991b). Bu durum kişinin görev performansını olumlu ya da olumsuz bir biçimde etkileyebilmektedir. Kobori ve Tanno (2005) araştırmalarında mükemmeliyetçi bireylerin kendilerine yönelik yüksek standartlar belirlemeleri doğrultusunda görevlerinde hata yaptıkları, bu hataların düzeltilmeleri neticesinde görev performanslarında olumlu değişimler gözlendiğini belirtmektedirler. Stoeber ve Childs (2010) başkalarına yönelik mükemmeliyetçiliğin bireylerin sorumlulukları ve işe özgü yeterlilikleriyle yakından ilgili olduğunu ortaya koymuşlardır. Bu yeterlilikler iş performansının, çalışan moralinin bozulması gibi etkileriyle bilinen tükenmişlik ve stres gibi faktörlerin de devreye girmesini tetiklemektedir (Taris vd. 2010). Çalışanların başkaları tarafından değerlendirilmeleri, eleştirilmeleri ya da takdir edilmeleri gibi örgüt için davranışların sebepleri arasında çalışanların arasındaki rekabet, birbirlerine katlanamamaları ve diğer bireylere odaklı suçlamalarda bulunmaları gibi sebepler bulunmaktadır (Flett vd. 1994). Bununla birlikte çalışanların başkalarınca belirlenen mükemmeliyetçilik özellikleri karşılıklı ilişkilerde kontrollü ve sorumlu davranışlar sergileme eğilimleri şeklinde de ortaya çıkmaktadır. Bu durum çalışanların birbirlerine doğrudan ve sert bir biçimde hitap etmeleri ya da birbirleriyle hiç konuşmamaları şeklinde sonuçlar yaratmaktadır (Habke ve Flynn 2002: 164).

Rice vd. (2005) bireyin başkalarına karşı ve başkalarının bireye karşı mükemmeliyetçi beklentileri, bireysel değeri ve işe karşı hevesi konu eden performans değerlemeleri ile ölçülebileceğini ifade etmektedirler. Mükemmeliyetçi birey, çevresinde bağlılık yaşadığı bireylere yine kendisinin belirlediği olağandışı yüksek standartlar ya da atıflar oluşturabilmektedir. Bu standartlar yerine getirilmediğinde sosyal eleştiri ve kınama gibi durumlarla karşı karşıya kalabilir (Dunkley vd. 2003). Alanyazın taraması sonucunda oluşturulan hipotezler Tablo 1'de gösterilmiştir.

\section{ARAŞTIRMANIN YÖNTEMI}

Araştırmada iki farklı ölçek ile çalışanların demografik özelliklerini tespit etmeye yönelik sorulardan oluşan bir form kullanılmıştır. Orijinali Hewitt ve Flett (1991a) tarafından geliştirilen, çok boyutlu mükemmeliyetçilik ölçeğinin (Multi-dimensional Perfectionism Scale) Oral (1999) tarafından Türkçeye uyarlanmış biçimi kullanılmıştır. Bireysel iş performans ölçeğinin hazırlanmasında Borman ve Motowidlo (1993) tarafından ortaya atılan görev performansı ve ortamsal (kurumsal) performans modeli ile Viswesvaran (1993) tarafından geliştirilen dokuz boyutlu performans modeli, 180 derece performans değerlendirme sistemi uygulanarak, otel işletmelerinde de sıklıkla kullanılan formata benzer şekilde İngilizce karşılıklarıyla birlikte hazırlanmıştır. İş görenlerin demografik özelliklerinin araştır- 
Tablo 1. Hipotezler Tablosu \begin{tabular}{l}
\hline Hipotez 1: Çalışanların kendine yönelik mükemmeliyetçilik özelliklerinin görev performansları üzerinde anlamlı bir etkisi bulunmaktadır. \\
\hline Hipotez 2: Çalışanların kendine yönelik mükemmeliyetçilik özelliklerinin ortamsal (kurumsal) performansları üzerinde anlamlı bir etkisi bulun- \\
maktadır. \\
\hline Hipotez 3: Çalışanların başkalarına yönelik mükemmeliyetçilik özelliklerinin görev performansları üzerinde anlamlı bir etkisi bulunmaktadır. \\
\hline Hipotez 4: Çalışanların başkalarına yönelik mükemmeliyetçilik özelliklerinin ortamsal (kurumsal) performansları üzerinde anlamlı bir etkisi \\
bulunmaktadır.
\end{tabular}

Hipotez 5: Çalışanların başkalarınca belirlenen mükemmeliyetçilik özelliklerinin görev performansları üzerinde anlamlı bir etkisi bulunmaktadır.

Hipotez 6: Çalışanların başkalarınca belirlenen mükemmeliyetçilik özelliklerinin ortamsal (kurumsal) performansları üzerinde anlamlı bir etkisi bulunmaktadır

Hipotez 7: Çalışanların Mükemmeliyetçi Beklentiler özelliklerinin görev performansları üzerinde anlamlı bir etkisi bulunmaktadır

Hipotez 8: Çalışanların Mükemmeliyetçi Beklentiler özelliklerinin ortamsal (kurumsal) performansları üzerinde anlamlı bir etkisi bulunmaktadır.

ma konusuna nasıl etki edeceği ve ne derecede önemli olacağını sınamak amacıyla hazırlanan kişisel bilgi formunda sekiz adet soru sorulmuştur.

Anket yoluyla toplanan bilgilerin analizinde sosyal bilimler için geliştirilmiş olan SPSS 19.0 istatistik paket programı kullanılmıştır. Veriler, tanımlayıcı ve çıkarımsal istatistik bazında ele alınmış, faktör analizi, T-testi, güvenirlilik analizi, varyans analizi, korelasyon analizi ve regresyon analizi ile test edilmiştir. Araştırmanın örneklem grubunun belirlenmesinde öncelikle alan yazındaki çalışmalar incelenmiştir. Himmetoğlu ve Tural'ın (1990) İzmir bölgesinde yaptıkları çalışmanın verilerine göre bir oda için düşen personel sayısı; üç yıldızlı otellerde 0,58 , dört yıldızlı otellerde 0,77 ve beş yıldızlı otellerde ise 1,05 olarak verilmiştir. Antalya Bölgesinde bulunan 106 otel örgütünde yapılan başka bir araştırmanın sonuçlarında otellerin bölümleri ve bu bölümlerde çalışan personelin toplam personele oranları yüzdeler halinde verilmiştir. Buna göre yiyecek ve içecek çalışanlarının tüm bölümler içindeki yerinin \%35-\%45 arasında olduğu ortaya konmuştur (Aktaş ve Boyacı 1995). Araştırmanın evrenini belirlemek üzere İstanbul bölgesinde bulunan bazı dört ve beş yıldızlı otellerin yöneticileriyle yapılan görüşmeler neticesinde personelin departmanlara göre dağılımları ve her departmanda çalışan yönetici aşçı sayıları belirlenmiş, ortaya çıkan rakamlar toplam oda sayısına bölünerek orta kademe yönetici aşçı sayıları beş yıldızlı, dört yıldızlı ve üç yıldızlı oteller bazında oran- lar yardımı ile tespit edilmiştir. Bu belirleme çalışması neticesinde beş yıldızlı otellerde 0.07 (748 aşçı), dört yıldızlı otellerde 0,05 (206 aşçı), üç yıldızlı otelde ise 0,035 (16 aşçı) olmak üzere toplam 970 kişi araştırmanın evrenini oluşturduğu sonucuna ulaşılmıştır. Anketler hazırlandıktan ve konu ile ilgili uzman öğretim üyelerinin görüşleri sistematik olarak alındıktan sonra Eylül 2011 Ocak 2012 tarihleri arasında gerek otel işletmelerinde gerekse aşçılık ve mutfak alanlarında İstanbul bölgesinde düzenlenen eğitim seminerlerinde uygulanması uygun görülmüştür. Uygulama sonunda 320 adet anket elde edilmiştir. Toplanan anketler araştırma evreninin \% 30'unu temsil etmektedir.

\section{ARAŞTIRMANIN BULGULARI VE TARTIŞMA}

Araştırmaya 320 kişi katılmıştır. Çalışanların dörtte biri kadındır (\%25) ve tüm çalışanların yarısından fazlası evlidir. Ankete katılanların büyük bir kısmının 22-42 yaş arası genç ve orta yaşta $(\% 83,8)$ aşçılar oldukları görülmektedir. Çalışanların yarısından fazlası (\%64) 10 yıldan daha az bir süredir bulundukları işletmede çalışmaktadırlar ki bu durum işletmelerde iş gören devrinin yüksek olmasının bir göstergesidir. Çalışanların \%63'ü lise ve daha düşük seviyede eğitim almıştır. Katılımcıların demografik bulguları Tablo 2'de gösterilmiştir.

\section{Güvenirlik ve Geçerlilik}

Verilerin faktör analizine uygunluğunda KMO örneklem yeterlilik değeri 0,849 olup, Bartlett kü- 
Tablo 2. Katılımcların Demografik Özelliklerine Göre Dağı̆lımı

\begin{tabular}{|c|c|c|}
\hline Cinsiyet & $n$ & $\%$ \\
\hline Kadın & 81 & 25,3 \\
\hline Erkek & 239 & 74,7 \\
\hline \multicolumn{3}{|l|}{ Yaş Dağılımı } \\
\hline 22-28 Arası & 63 & 19,7 \\
\hline 29-35 Arası & 117 & 36,6 \\
\hline 36-42 Arası & 88 & 27,5 \\
\hline 43-49 Arası & 25 & 7,8 \\
\hline 50 ve Üzeri & 24 & 7,5 \\
\hline \multicolumn{3}{|l|}{ Eğitim Durumu } \\
\hline Ilköğretim & 86 & 26,9 \\
\hline Lise & 113 & 35,3 \\
\hline Ön-Lisans & 81 & 25,3 \\
\hline Lisans ve üstü & 40 & 12,5 \\
\hline \multicolumn{3}{|l|}{ Medeni Durum } \\
\hline Bekâr & 115 & 35,9 \\
\hline Evli & 205 & 64,1 \\
\hline \multicolumn{3}{|l|}{ İ̧̧ Yerindeki Ünvânı } \\
\hline Şef Yardımcısı & 94 & 29,4 \\
\hline Kısım Şefi & 111 & 34,7 \\
\hline Kısım Şefi yardımcısı & 97 & 30,3 \\
\hline Diğer & 18 & 5,6 \\
\hline \multicolumn{3}{|l|}{ Meslek çalışma Süresi } \\
\hline $1-5 Y_{I} \mid$ & 24 & 7,5 \\
\hline 6-10 Yıl & 74 & 23,1 \\
\hline 11-15 Yıl & 103 & 32,2 \\
\hline $16-20 Y_{\imath} l$ & 52 & 16,3 \\
\hline 21 Yıl ve üzeri & 67 & 20,9 \\
\hline \multicolumn{3}{|c|}{ Işletmede Çalışma Süresi } \\
\hline Bir Yıldan Az & 57 & 17,8 \\
\hline $1-5 Y_{I}$ & 107 & 33,4 \\
\hline 6-10 Yıl & 98 & 30,6 \\
\hline 11 Yıl ve üzeri & 58 & 18,1 \\
\hline \multicolumn{3}{|l|}{ Meslek Kararı } \\
\hline Kendi Kararım & 251 & 78,4 \\
\hline Ailemin Kararı & 69 & 21,6 \\
\hline
\end{tabular}

resellik testi sonuçları da anlamlı çıkmıştır. Her iki test sonucuna bakıldığında Çok Boyutlu Mükemmeliyetçilik Ölçeği'ne ilişkin verilere faktör analizi yapılmasının uygun olacağına karar verilmiştir.

Yapılan faktör analizi sonucunda anti-imaj değerleri incelenmiş, 0,50'nin altında kalan sorular teker teker ölçek dışı bırakılarak her defasında faktör analizi tekrarlanmıştır. Soruların ölçekten atılması ve yapılan analizler sonucunda Çok Boyutlu Mükemmeliyetçilik Ölçeği'ne ilişkin özde- ğerleri bir ve üzerinde olan dört faktörlü bir yap1 ortaya çıkmıştır. Ölçeğin uygulanmasından elde edilen veriler ile ölçeğin faktör yapısının belirlenmesi amacıyla yapılan faktör analizinde birbirinden bağımsız dört faktör ile ölçekten elde edilen verilerde gözlenen değişimin \%64,373'ünün açılanması mümkün olmuştur.

Orijinal ölçekte Hewitt ve Flett (1991a) ve Türkçeye uyarlama çalışmasında (Oral 1999) üç faktörlü çözüm kullanılmış olmasına karşın araştırmada dört faktörlü bir sonuca ulaşılmıştır. Bununla birlikte alanyazındaki çalışmalar incelendiğinde, başkalarına yönelik mükemmeliyetçilik değişkeni farklı isimler altında kullanılmış ya da yeni değişkenler ile ifade edilerek farklı faktörler geliştirilmiştir (Ashby ve Kottman 1996). Enns ve Cox (2002) ölçekteki ifadelerin daha genellenebilir olmaları için azaltılması gerektiğini savunarak, ölçeğin faktör sayısının da arttırılabileceğini savunmuştur. Benzer bir sonuçla Selışık (2003) çalışmasında ölçek maddelerinden sekiz tanesini çıkararak dördüncü bir faktör bulmuş ve çalışmasında kullanmıştır. Çalışmada ortaya çıkan bu yeni faktör "Mükemmeliyetçi Beklentiler" olarak adlandırılmış ve oluşturulan yeni hipotezler de çalışmaya dâhil edilmiştir. Tablo 3'te Çok Boyutlu Mükemmeliyetçilik Ölçeği için yapılan açıklayıcı faktör analiz sonuçları bulunmaktadır.

Tablo 4'te Bireysel Performans Ölçeği için yapılan açılayıcı faktör analiz sonuçları bulunmaktadır. KMO örneklem yeterlilik değeri ve Bartlett küresellik testi sonucuna bakıldığında Bireysel Performans Değerlendirme Ölçeğine ilişkin verilere faktör analizi yapılmasının uygun olacağına karar verilmiştir. Bireysel performans değerlendirme ölçeğine ilişkin özdeğerleri bir ve üzerinde olan iki faktörlü bir yapı ortaya çıkmıştır. Faktörlerin güvenilirlik analizleri yapıldığında her iki faktörün de $\% 70$ güvenilirlik düzeyinin üstünde olduğu tespit edilmiştir. Elde edilen iki faktöre ilişkin toplam açıklanan varyans $\% 62,262$ olarak bulunmuştur. Ortaya çıkan bu sonuçlara göre tüm ifadelerin faktör yüklerinin 0,50 üzerinde olması maddelerin içinde bulunduğu yapı ile uyum sağladığını göstermektedir. 
Tablo 3. Çok Boyutlu Mükemmeliyetçilik Ölçeği Faktör ve Güvenilirlik Analizleri

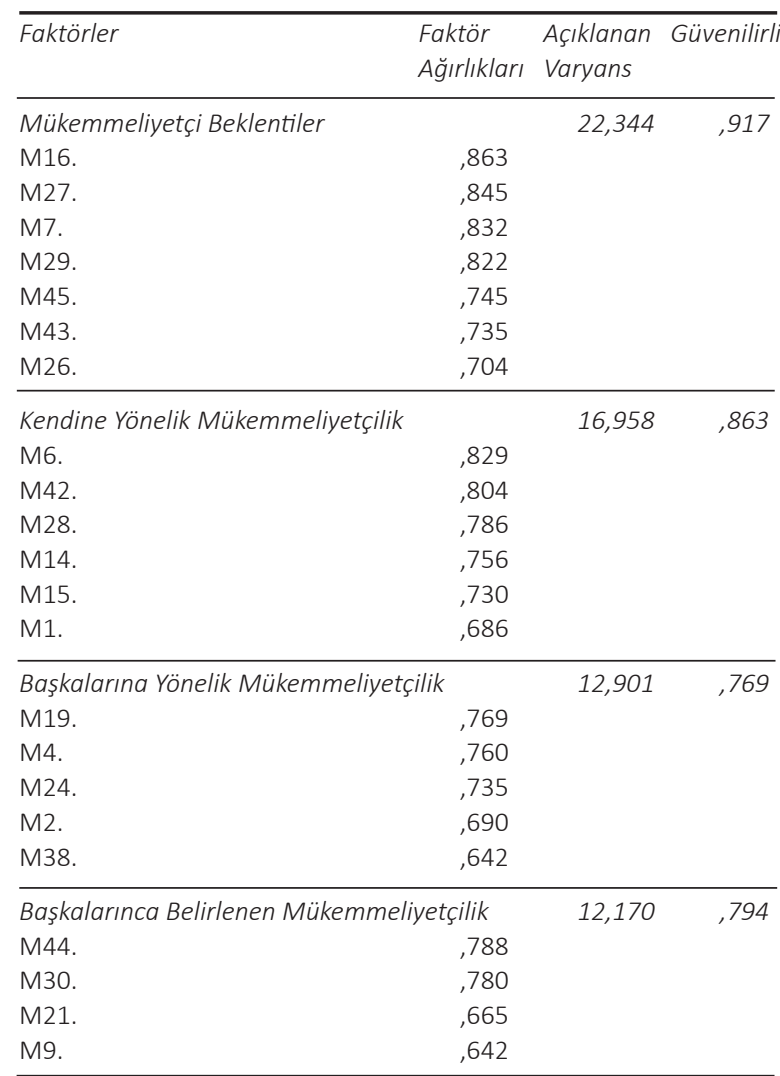

Not: Varimax Rotasyonlu Temel Bileşenler Faktör Analizi. KMO Örneklem Yeterliliği=,849 Bartlett Testi Anlamlılığgl= p<,000 (Kikare değeri $=3779,381$, Serbestlik Derecesi $(\mathrm{df})=231)$.

\section{Regresyon Analizi ve Sonuçlarının Değerlendirilmesi}

Görev performansı bağımlı değişkeni ile mükemmeliyetçilik faktörleri arasındaki ilişkinin tespitine yönelik olarak yapılan regresyon analiz sonuçlarında R2 değerinin ,156 olarak hesaplandığı ve görev performansını \%15,6 oranında açıkladığ1 görülmektedir. Varyans analizi tablosunda ise anlamlılık değeri 0,001 çıktığından dolayı regresyon sonuçları anlamlıdır. Görev performansı ile mükemmeliyetçilik faktörleri arasındaki regresyon sonuçları Tablo 5'te gösterilmiştir.

Regresyon analizi sonucunda ortaya çıkan faktörlerden mükemmeliyetçi beklentiler faktörü ve başkalarına yönelik mükemmeliyetçilik faktörler anlamlılık değeri 0,05'ten küçük çıktığından dolayı, görev performansı isimli bağımlı değişken üzerinde istatistiksel olarak anlamlı etkisi olduğu ortaya çıkmıştır. Bu sonuçla dördüncü hipotez kabul edilmiştir.

Kurumsal (ortamsal) performans bağımlı değişkeni ile mükemmeliyetçilik faktörleri arasındaki ilişkinin tespitine yönelik olarak yapılan regresyon analiz sonuçlarında R2 kurumsal (ortamsal) performansı \%31,9 oranında açıklanmaktadır. Varyans analizi tablosunda ise anlamlılık değeri 0,001 olduğundan dolayı regresyon sonuçları anlamlıdır. Kurumsal Performans ile Mükemmeliyetçilik faktörleri arasındaki regresyon sonuçları Tablo 6'da verilmektedir.

Sosyal bilimler alanında araştırma yapan bazı akademisyenler, çalışmanın verilerinin analizinden sonra ortaya çıkan regresyon testlerindeki R2 değerlerinin düşük olmasını modeldeki bağımsız değişkenlerin bağımlı değişkeni açıkla-

Tablo 4. İş Performansı Değerlendirme Ölçeği Faktör ve Güvenilirlik Analizleri

\begin{tabular}{lrr}
\hline Faktörün Adı & Faktör Ağırlıkları & Açıklanan Varyans \\
\hline Görev Performansı Faktörü & $\% 26,298$ \\
Üretkenlik (Productivity) &, 811 &, 730 \\
Çaba (Effort) &, 723 &, 673 \\
İş Bilgisi (Job Knowledge) &, 586 & $\% 35,964$ \\
Kalite (Quality) &, 862 \\
\hline Kurumsal (Ortamsal) Performans Faktörü &, 817 \\
Iletişim Yetkinliği (Communication Competence) &, 773 \\
Kişiler Arası Ilişkilerde Yetkinlik (Interpersonal Competence) &, 737 \\
Liderlik (Leadership) &, 860 \\
İdari Yetkinlik (Administative Competence) &, 595 \\
\hline Kurallara Uyma ve Otoritenin Kabulü & \\
(Compliance and Acceptance of Authority) & \\
\hline
\end{tabular}

Not: Varimax Rotasyonlu Temel Bileşenler Faktör Analizi. KMO Örneklem Yeterliliği =,889 Bartlett Testi Anlamlılı̆̆l= p<,000 (Ki-kare değeri=1820,274, Serbestlik Derecesi $(\mathrm{df})=45)$. 
Tablo 5. Görev Performansı Regresyon Analizi Sonuçları

\begin{tabular}{|c|c|c|c|c|c|}
\hline Bağımsız Değişkenler & Beta & $T$ & $p$ & $R^{2}$ & Anlamlılık \\
\hline Sabit & $-2,513 E-016$ &, 000 & 1,000 & & \\
\hline Mükemmeliyetçi Beklentiler &,- 265 & 5,124 &, $000 * * *$ & & \\
\hline Kendine Yönelik Mükemmeliyetçilik & ,046 & ,882 &, 378 & & \\
\hline Başkalarına Yönelik Mükemmeliyetçilik & ,287 & 5,538 &, $000 * * *$ & ,156 & $F=14,549$ \\
\hline Başkalarınca Belirlenen Mükemmeliyetçilik & ,036 & ,700 & ,484 & & $p=, 000$ \\
\hline
\end{tabular}

***: $\mathrm{p}<0,05$

maya yetmediği ve modelin uyum iyiliğinin düşük olduğu şeklinde yorumlamaktadırlar. Bu değerlerin düşük olmasına rağmen yine de çalışmanın sonuçlarının kabul edilebilmesini sağlayan başlica sebepler;

a) Çalışmanın konusunun Psikoloji ve Psikopatoloji gibi tıp bilimlerine yakın olan bir kaynaktan gelmesi ve tıp bilimlerinde R2 değerlerinin düşük olsa bile, t değerlerinin ikinin üstünde olması durumda çıkan sonucun anlamlı olarak kabul edilmesi (Colton ve Bower 2002).

b) Çalışmanın Psikoloji bilimiyle alakalı olması ve bu bilim dalındaki ölçüm problemi sebebiyle R2 değerlerlerinin düşük olması kabul edilebilir bir durumdur. Bireysel özellikleri ve performans etkileşimini yıllardır araştıran akademisyenler belirli bir model üzerinde anlaşamamaktadırlar. $\mathrm{Bu}$ anlaşmazlığın en önemli nedeni, genel kabul görmüş ilişki analizlerine dair oranların, yapılan araştırmalarda düşük çıkması (Ghiselli 1973; Reilly ve Chao 1982) şeklinde açıklanabilir.

Regresyon analizi sonucunda ortaya çıkan bulgular 1şığında, kendine yönelik mükemmeliyetçilik, başkalarına yönelik mükemmeliyetçilik, başkalarınca belirlenen mükemmeliyetçilik ve mükemmeliyetçi beklentiler faktörlerinin kurumsal (ortamsal) performans isimli bağımlı değişken üzerinde istatistiksel olarak anlamlı bir etkisi olduğu, ancak bu etkinin sinırlı olduğu ortaya çıkmıştır. H2, H4, H6, H8 hipotezleri kabul edilmektedir. Bu sonuç daha önce belirtildiği üzere alanyazındaki bazı araştırmalar tarafından da desteklenmektedir (Anshel ve Mansouri 2005; Stoeber ve Eysenck 2008; Monck 2009).

Yazında farklı örneklemler üzerinde yapılan çalışmalarda kendine yönelik mükemmeliyetçiliğin performansı etkilediğine dair sonuçlara ulaşılmasına rağmen bu çalışmada aşçıların kendilerine ulaşılması güç standartlar belirlemelerinin görev performansları üzerinde herhangi bir etkisi olmadığı sonucu ortaya çıkmaktadır. H1 Hipotezi reddedilmiştir. Bunun sebepleri arasında; a) uluslararası otel örgütlerinde kullanılmakta olan kalite sistemlerinin aşçıbaşı ve altında çalışan orta kademe yöneticileri belirli bir standartta sınırlaması, b) yapılacak işlerin yoğunluğu ile temel performans çıktılarından biri olan kalitenin önceden belirlenen düzeyde tutulmak istenmesi ve c) çalışma performansının işverenin gözüyle "yalnızca değer verilen davranışlar" (Yelboğa 2006) olarak görülmesi sayılabilir.

Tablo 6. Kurumsal (Ortamsal) Performans Regresyon Analizi Sonuçları

\begin{tabular}{|c|c|c|c|c|c|}
\hline Bağımsız Değişkenler & Beta & $T$ & $p$ & $R 2$ & Anlamlılık \\
\hline Sabit & 4,215E-017 &, 000 & 1,000 & & \\
\hline Mükemmeliyetçi Beklentiler & ,423 & 9,148 &, $000 * * *$ & & \\
\hline Kendine Yönelik Mükemmeliyetçilik & ,272 & 5,891 &, $000 * * *$ & $F=38,316$ & \\
\hline Başkalarına Yönelik Mükemmeliyetçilik &,- 146 & $-3,166$ &, $002 * * *$ & 319 & $p=, 000$ \\
\hline Başkalarınca Belirlenen Mükemmeliyetçilik & ,230 & 4,986 & $, 000 * * * * * *: p<0,05$ & & \\
\hline
\end{tabular}

***: $\mathrm{p}<0,05$ 
Çalışmanın sonuçları itibarıyla mükemmeliyetçi beklentiler ve başkalarına yönelik mükemmeliyetçiliğin, görev performansına düşük bir oranda etki ettiğini söylemek mümkündür. Dolayısıyla H3 ve H7 kabul edilmiştir. Mutfak örgütlerinde aşçıbaşı ve ona bağlı bulunan astlar tarafından verilen emirler eksiksiz yerine getirilir, sorgulamak ya da bazı durumlarda açıklamalarda bulunmalarını istemek gibi isteklerin mesleğin görünmez ilkelerine ters düştügü bilinmektedir (Pratten 2003: 455). Bu durum aşçılarda şiddetli geçimsizliğe, devamsızlığa ve iş bırakmaya sebep olabilir (Johns ve Menzel 1999: 104). Ancak ülkemizdeki mutfak sisteminde bu durumun çok fazla önem teşkil etmediği, bir başka anlatımla aşç-ların diğer aşçıları ve üstleri sorgulamalarının iş performansına çok fazla etki etmediği görülmektedir. Aubert ve Kelsey (2003) takım çalışmasının yarattığı bireyler arası farklılıklardan doğan çatışmaların çalışanların bireysel performansına değil, takım performansına etki etmesinin esas nedeninin bireyler arasındaki güven derecesi ile ilgili olduğunu belirtmektedirler.

Çalışanların başkalarınca belirlenen mükemmeliyetçilik özelliklerinin görev performansları üzerinde anlamlı bir etkisi bulunmamaktadır (H5 Red). Aşçıların iyi ya da kötü iş yaptıkları gerekçesiyle başkaları tarafından yapılan değerlemeler, mutfağın genelini ilgilendirebileceği gibi çalışılan işletmenin mutfağını genel olarak hata yapma davranışlarına ve korkusuna iteceği de unutulmamalıdır (Tziner ve Tanami 2013). Orta kademe aşçıların mükemmeliyetçi beklentileri görev düzeyindeki beklentiler, sosyal düzeydeki beklentiler ve örgüt düzeyindeki beklentiler olarak ifade edildiği için (Tett ve Burnett 2003), bu beklentilerin karşılanamaması durumunda aşç1ların performansında düşüşler yaşanabilmektedir.

\section{SONUÇ VE ÖNERILER}

Alanyazın incelemesi ve hipotezlerin test edilmesi sonucunda, akademik alanda yapılmış olan mükemmeliyetçilik ve iş performansı arasındaki ilişki ve etkileşimi ölçen çalışmaların sınırlı olduğu tespit edilmiştir. Dolayısıyla, bu çalışmanın turizm işletmeciliği, yönetim ve örgütsel davranış alanlarında var olan boşluğun doldurulma- sına yardımcı olacağı düşünülmektedir. Bundan sonra yapılacak çalışmalarda evren büyüklügü arttırılarak daha genellenebilir sonuçlar elde edilmesi sağlanabilir.

Bu çalışmanın sonucunda mükemmeliyetçiliğin iş performansı üzerinde istatistiksel olarak anlamlı bir etkisi olduğu, ancak bu etkinin sınırlı olduğu ortaya çıkmıştır. Alanyazında söz konusu etkileşimi irdeleyen çalışmaların polis memurları (Hrabluik 2009), ergen ve okul çağındaki gençler (Rice ve Dwello 2002; Stoeber ve Eysenck 2008) ve sporcular (Anshel ve Mansouri 2005) örneklem grupları üzerinde test edildiği ve bu çalışmalarda mükemmeliyetçiliğin akademik ve çalışma yaşamına yüksek oranda etki ettiği görülmektedir. Ancak sanatçılarda yapılan bir çalışmanın mükemmeliyetçiliğin iş performansına herhangi bir anlaml etkisi olmadığ $\breve{1}_{1}$ sonucu ortaya konmuştur (Mor vd. 1995: 218). Bu durum farklı mesleklerin doğası gereği ortaya çıkan, keşifçilik (yaratıcllık), güncel mesleki eğilimler, isteğe göre değiştirilebilen tat ve lezzet gibi o mesleği diğerlerinden ayıran ve performansı farklı şekillerde etkileyebilecek kriterlerin de olduğunu açıklamaktadır. Bir başka deyişle sanatçılık veya aşçılık gibi mesleklerde günlük rutin işlerde mükemmeliyetçilik etkili olabilir, ancak bu işlerin yapılması esnasında söz konusu kriterler ortaya çıtığında kişilerin mükemmeliyetçi tutumlarında azalma görülebilir. Yapılacak ileriki çalışmalarda farklı mesleklerin doğası gereği ortaya çıan bu kriterler ile mükemmeliyetçilik ya da diğer kişilik özelliklerinin etkileşimleri araştırılmalıdır.

Çalışmanın bağımsız değişkeni olan mükemmeliyetçilik değişkenini ölçmek için kullanılan alanyazında konu ile ilgili çalışmalarda bulunan araştırmacıların geliştirdikleri farklı ölçeklerin ve farklı örneklem gruplarının kullanılması daha farklı hipotezlerin sinanmasina ve farklı bulgulara ulaşmaya yardımcı olacaktır. Ayrıca bu alanda gelecekte yapılacak çalışmalarda bireysel performanstan öte takım performansının incelenmesi yararlı olabilir.

Mükemmeliyetçilik; iyi yönetilmediği hallerde, çalışanın stres, depresyon, anksiyete gibi iş yaşaminda sıklıkla rastlanan durumların tetikleyicisi olabilir. Bu durumlar sonunda kişilerin işten ay- 
rılmaları, işletmeler için oldukça sağlıksız bir sonuç yaratabilir. Bu açıdan kısım şefleri ve insan kaynakları müdürleri çalışanlarını iyi gözlemlemeli ve sorunları çözmek için çalışmalar yapmalidirlar.

\section{KAYNAKÇA}

Anshel, H.M. ve Mansouri, H. (2005). Influence of Perfectionism on Motor Performance, Affect, and Causal Attributions in Response to Critical Information Feedback, Journal of Sports Behavior, 28: 99-124,

Ashby, J.S. ve Kottman, T. (1996). Inferiority as a Distinction Between Normal and Neurotic Perfectionism, Individual Psychology, 52: 237-245.

Aubert, B.A. ve Kelsey, B.L. (2003). Further Understanding of Trust and Performance in Virtual Teams, Small Group Research, 34: 575-618.

Baker, R. ve Newport, S. (2003). Dysfunctional Managerial Behaviour in The Workplace: Implications for Employees, Supervisors, and Organisations, Problems and Perspectives of Management, 1 (1): 108-113.

Borman, W.C. (1990). Job Behavior, Performance and Effectiveness. İçinde M.D. Dunette ve L.M. Hough (Editörler), Handbook of Industrial/Organizational Psychology (ss. 271- 326). Consulting Psychologists Press, Palo Alto, CA.

Borman, W.C. Motowidlo S.J. (1993). Expanding The Criterion Domain to Include Elements of Contextual Performance. İçinde N. Schmitt and W. C. Borman (E d i tö r ler), Personnel Selection in Organizations. Jossey-Bass, San Francisco. 71-98.

Bousman, L.A. (2007). The Fine Line Of Perfectionism: Is It A Strength or Weakness in the Workplace (Yayımlanmamış Doktora Tezi),Nebraska: Nebraska Universitesi.

Campbell, J.P. (1990). Modeling The Performance Prediction Problem in Industrial And Organizational Psychology. İçinde M. D. Dunette ve L. M.Hough (Editörler), Handbook of Industrial/OrganizationalPsychology. Consulting Psychologists Press, Palo Alto, CA. 2 (1): 687-732.

Childs, J.H. ve Stoeber, J. (2010). Self-oriented, Other-Oriented, And Socially Prescribed Perfectionism İn Employees: Relationships With Burnout And Engagement, Journal of Workplace Behavioral Health, 25: 269-281.

Colton, J.A. ve Bower, K.M. (2002). Some Misconceptions About R2, International Society of Six Sigma Professionals, 3 (2): 20-22.

Dunkley, D.M., Zuroff, D.C. ve Blankstein. K. R. (2003). SelfCritical Perfectionism and Daily Affect: Dispositional and Situational Influences on Stress and Coping, Journal of Personality and Social Psychology, 84: 234-252.

Eburne, J.P. (2010). The Chef Drive: Cooking Beyond the Pleasure Principle, Contemporary French and Francophone Studies,14: 169-177.

Enns, M.W. ve Cox B.J. (2002). The Nature and Assessment of perfectionism: A Critical Analysis, İçinde Gordon L. Flett ve Paul L. Hewitt (Editörler) Perfectionism: Theory, Research, and Treatment. Washington, DC: American Psikoloji Derneği.
Fairlie, P. ve Flett, G.L. (2003, August). Perfectionism at Work: Impacts on Burnout, Job Satisfaction, and Depression. Poster presented at the 111th Annual Convention of the American Psychological Association, Toronto, Ontario, Canada.

Flett, G.L., Hewitt P.L., Blankstein K.R. ve Dynin C.B. (1994). Dimensions Of Perfectionism and Type A Behaviour, Personality And Individual Differences, 16: 477-485.

Flett, G.L. ve Hewitt P.L. (2002). Perfectionism And Maladjustment: An Overview of Theoretical, Definitional, and Treatment Issues. İçinde Gordon L. Flett ve Paul L. Hewitt (Editörler) Perfectionism: Theory, Research, and Treatment. Washington, DC: American Psikoloji Derneği.

Frost, R.O., Marten P., Lahart C. ve Rosenblate R. (1990) The Dimensions of Perfectionism, Cognitive Therapy And Research, 14 (5): 449-468.

Ghiselli, E.E. (1973). The Validity of Aptitude Tests in Personnel Selection, Personnel Psychology, 26: 461-477.

Greenhaus, J.H. ve Powell, G.N. (2006). When Work and Family are Allies: A Theory of Work-Family Enrichment, Academy of Management Review, 31 (1): 72-92.

Habke, A.M. ve Flynn, C.A. (2002). Interpersonal Aspects of Trait Perfectionism. İçinde Gordon L. Flett ve Paul L. Hewitt (Editörler) Perfectionism: Theory, Research, and Treatment. Washington, DC: American Psikoloji Derneği.

Hewitt, P.L. ve Flett, G.L. (1991a). Dimensions Of Perfectionism in Unipolar Depression, Journal of Abnormal Psychology, 100: 98-101.

Hewitt, P.L. ve Flett, G.L. (1991b). Perfectionism in the Self and Social Contexts: Conceptualization, Assessment, and Association with Psycho-Pathology, Journal of Personality and Social Psychology, 60: 456-470.

Hill, R.W., Zrull, M.C. ve Turlington, S. (1997). Perfectionism And Interpersonal Problems, Journal of Personality Assessment, 69: 81-103.

Horney, K. (1996). New Ways of Psychoanalysis. New York: W.W. Norton \& Company.

Hralbuik, C. (2009). The Dark Side of Goal Setting: Examining The Relationship Between Perfectionism and Maximum Versus Typical Employee Performance, (Yayımlanmamış Doktora Tezi). Toronto: Toronto Üniversitesi Joseph L. Rothman Yönetim Okulu.

Johns, N. ve Menzel, P. J. (1999). 'If You Can't Stand The Heat! Kitchen Violence and Culinary Art, Hospitality Management, 18: 99-109.

Kobori, O. ve Tanno, Y. (2005). Self-Oriented Perfectionism and its Relationship to Positive and Negative Effect: The Mediation of Positive and Negative Perfectionism Cognitions, Cognitive Theraphy And Research, 29 (5): 555567.

Landy, F.J. ve Farr, J.L. (1980). Performance Rating, Psychological Bulletin, 87 (1): 72-107.

Monck, L. (2009). The Impact of Perfectionism on Work Attitudes and Behavior, (Yayımlanmamış Doktora Tezi). New York: New York Şehir Üniversitesi.

Mor, S., Hy, D.I. ve Flett, G.L. (1995). Perfectionism, Control, and Components of Performance Anxiety in Professional Artists, Cognitive Therapy and Research, 19: 207-225. 
Oral, M. (1999). The Relationship Between Dimensions of Perfectionism, Stressful Life Events and Depressive Symptoms in University Students: A Test of DiathesisStress Model of Depression (Yayımlanmamış Yüksek Lisans Tezi). Ankara: Ortadoğu Teknik Üniversitesi.

Pratten, J.D. (2003). What Makes A Great Chef?, British Food Journal, 105 (7): 454-459.

Reilly, R.R. ve Chao, G.T. (1982). Validity And Fairness of Some Alternative Selection Procedures, Personnel Psycho$\log y, 35:$ 1-62.

Rice, K.G. ve Dwello, J.P. (2002). Perfectionism And SelfDevelopment: Implications for College Adjustment, Journal of Counselling $\mathcal{E}$ Development, 80: 194-195.

Rice, K.G., Lopez, F.G. ve Vergara, D. (2005). Potential/Social Influences on Perfectionism and Adult Attachment Orientations, Journal of Social and Clinical P s y cho$\log y, 24$ (4): 580-605.

Selışık, Z.E.S. (2003). The Dimensions of Perfectionism and Their Relations to Helpless Explanatory Style (Yayımlanmamış Yüksek Lisans Tezi). Ankara: Ortadoğu Teknik Üniversitesi.

Sherry, S.B., Hewitt, P.L., Sherry, D.L., Flett, G.L. ve Graham, A.R. (2010). Perfectionism Dimensions And Research Productivity in Psychology Professors: Implications for Understanding The (Mal) Adaptiveness Of Perfectionism, Canadian Journal of Behavioural Science, 42: 273283.

Slaney, R.B., Rice, K.G., Mobley, M., Trippi, J. ve Ashby, J.S. (2001). The Revised Almost Perfect Scale, Measurement and Evaluation in Counselling and Development, 34 (3): 130-145.

Sonnentag, S. ve Frese, M. (2002). Performance Concepts and Performance Theory. İçinde Sabine Sonnentag (Editör), Psychological Management of Individual Performance: A Handbook in The Psychology of Management in Organizations. Chichester: Wiley.

Steinberger, M. (2016). Michelin and The Death Of Two French Chefs. The New Yorker. http://www.newyorker. com/culture/culture-desk/michelin-and-the-deaths-of-twofrench-chefs, Erişim tarihi: 20 Mayss 2017.

Stoeber, J. ve Childs, J.H. (2010). The Assesement of SelfOriented and Socially Prescribed Perfectionism: Subscales Make a Difference, Journal of Personality Assessment, 92 (6): 577-585.
Stoeber, J., Davis, C.R. ve Townley, J. (2013). Perfectionism and Workaholism in Employees: The Role Of Work Motivation, Personality and Individual Differences, 55: 733-738.

Stoeber, J. ve Eysenck, M.W. (2008). Perfectionism and Efficiancy Accuracy, Response Bias And Invested Time in Proof Reading Performance, Journal Of Research in Personality, 42: 1673-1678.

Stoeber, J. ve Stoeber, F.S. (2009). Domains of Perfectionism: Prevalence And Relationships With Perfectionism, Gender, Age, And Satisfaction With Life, Personality and Individual Differences, 46: 530-535.

Taris, T.W., Beek I.V. ve Schaufeli W.B. (2010). Why Do Perfectionists Have a Higher Burnout Risk Than Others? The Mediational Effect of Workaholism, Romanian Journal Of Applied Psychology, 12 (1): 1-7.

Tuncer, B. (2006). Kaygı Düzeyleri Farklı Üniversite Hazırlık Sınıfı Öğrencilerinin Mükemmeliyetçilik Özelliklerinin İncelenmesi (Yayımlanmamış Yüksek Lisans Tezi). Ankara: Hacettepe Üniversitesi.

Tziner, A. ve Tanami, M. (2013). Examining the Links Between Attachment, Perfectionism, and Job Motivation Potential With Job Engagement And Workalcoholism, Journal Of Work And Organizational Psychology, 29: 65-74.

Ulu, İ.P. (2007). An Investigation of Adaptive and Maladaptive Dimensions of Perfectionism in Relation to Adult Attachment and Big Five Personality Traits (Yayımlanmamış Doktora Tezi). Ankara: Ortadoğu T e k n i k Üniversitesi.

Viswesvaran, C. (1993). Modeling Job Performance: Is There A General Factor? (Yayımlanmamış Doktora Tezi). Iowa: Iowa Universitesi.

Wittenberg, K.J. ve Norcross, J.C. (2001). Practitioner Perfectionism: Relationship To Ambiguity Tolerance And Work Satisfaction, Journal of Clinical Psychology, 57: 1543-1550.

Yelboğa, A. (2006). Bireylik Özellikleri ve İş Performansı Arasındaki İlişkinin İncelenmesi, İş Güç Endüstri İlişkileri ve Insan Kaynaklarn Dergisi, 8 (2): 196-211.

Zetie, S., Sparrow, J., Woodfield, A. ve Kilmartin, T. (1994). The Tyrannical Chef: A Barrier to TQM?, International Journal of Contemporary Hospitality Management, 6 (7): $42-45$. 

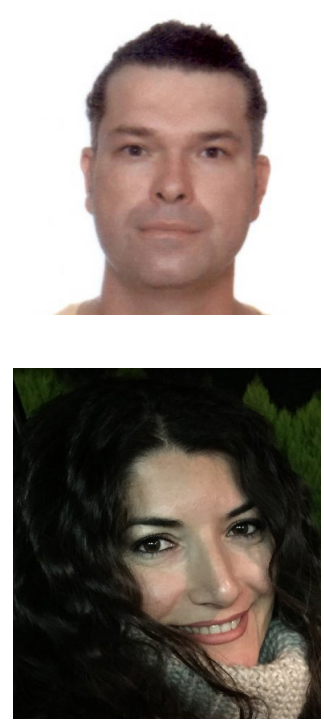

\section{Serdar EREN}

Balıkesir Üniversitesi Turizm İşletmeciliği Bölümü'nden mezun oldu (1999). Yüksek lisans derecesini İstanbul Ticaret Üniversitesi'nden İşletme Anabilim Dalından (2004), doktora derecesini de Dokuz Eylül Üniversitesi'nden Turizm İşletmeciliği Anabilim Dalından aldı (2013). İstanbul Ticaret Üniversitesi'nde öğretim görevlisi olarak çalıştı (2005-2014). Halen Serbest Araştırmacı ve Gezgin olarak dünyanın çeşitli bölgelerinde Gastronomi ve Kültür üzerine araştırmalar yapmaktadır. Temel çalışma alanı/ları Turizm İşletmeciliği, Gastronomi ve Mutfak Sanatları'dır.

\section{Ebru GÜNLÜ KÜÇÜKALTAN}

Dokuz Eylül Üniversitesi İșletme Fakültesi Turizm İșletmeciliği Bölümü’nden mezun oldu (1998). Yüksek lisans derecesini Dokuz Eylül Üniversitesi'nden Turizm İşletmeciliği Anabilim Dalından (2000), doktora derecesini de Dokuz EyIül Üniversitesi'nden Turizm İşletmeciliği Anabilim Dalından aldı (2003). Dokuz Eylül Üniversitesi'nde çalışmaya başladı (1998). Doçentlik unvanını Yönetim ve Organizasyon alanında aldı (2011). Profesörlüğe Dokuz Eylül Üniversitesi'nde yükseltildi (2016). Halen Dokuz Eylül Üniversitesi İşletme Fakültesi'nde görev yapmaktadır. Temel çalışma alanı/ları Turizm İşletmeciliği, Yönetim ve Organizasyon'dur. 